Short Communication

\title{
Corrosion Behavior of 2Cr12MoV Turbine Steel in Early Condensate in the Presence of Acetic Acid
}

\author{
Jiaqiang Wei, Baiqing Zhou*
}

School of Power and Mechanical Engineering, Wuhan University, No.8 South East Lake Road, Wuchang District, Wuhan City, Hubei Province, 430072, People's Republic of China

*E-mali: zhoubaiqing5@163.com

doi: $10.20964 / 2017.03 .11$

Received: 5 December 2016 / Accepted: 29 December 2016 / Published: 12 February 2017

The corrosion behavior of $2 \mathrm{Cr} 12 \mathrm{MoV}$ turbine steel in early condensate in the presence of acetic acid was studied by weight loss test, surface analysis and Potentiodynamic polarization. The results showed that acetic acid accelerate corrosion of $2 \mathrm{Cr} 12 \mathrm{MoV}$ turbine steel to some extent. By the concentration of acetic acid in solution increased to $5 \mathrm{ppm}$, anodic polarization behavior of $2 \mathrm{Cr} 12 \mathrm{MoV}$ turbine steel changes form active behavior to active, passive, and transpassive behavior. The critical passivation current density for $2 \mathrm{Cr} 12 \mathrm{MoV}$ turbine steel in HAc solution is about $78 \mu \mathrm{A} / \mathrm{cm}^{2}$, with the increase of acetic acid concentration, the active-passive transition potential moves to the negative direction and the passsive zone widened. The passivation of $2 \mathrm{Cr} 12 \mathrm{MoV}$ steel is attributed to the formation of $\mathrm{Fe}(\mathrm{Ac})_{2}$ layer.

Keywords: Blade steel, Acid corrosion, Acetic acid, Early condensate

\section{$\underline{\text { FULL TEXT }}$}

(C) 2017 The Authors. Published by ESG (www.electrochemsci.org). This article is an open access article distributed under the terms and conditions of the Creative Commons Attribution license (http://creativecommons.org/licenses/by/4.0/). 